\title{
A COMPARATIVE STUDY FOR IMPACT OF LOW PHOSPHORUS FERTILIZATION IN DIFFERENT COMBINATIONS WITH SULPHUR, GYPSUM AND PHOSPHOREIN ON TOMATO GROWTH, MINERAL STATUS AND PRODUCTIVITY. \\ EL-Said, M. E. \\ Vegetable Dept., Hort. Res. Inst.,Agric. Res. Centre, Cairo, Egypt.
}

ABSTRACT

Two field experiments were conducted at Kalabshow district, Dakahlia Governorate during two successive summer seasons of 2007 and 2008 to study the effect of phosphorus fertilizers,i.e., super phosphate and rock phosphate in different combination with gypsum, sulphur and phosphorein on growth ,mineral composition and productivity of tomato $\mathrm{cv}$. Super marmand. The experiment included fourteen treatments arranged in randomized complete block design. The treatments contained two sources of phosphorus (P) fertilizers [super phosphate (SP) and rock phosphate $(\mathrm{RP})$ at $100 \%$ from recommended dose $(\mathrm{RD})$,i.e, $75 \mathrm{KgP}_{2} \mathrm{O}_{5}$ ] and different combination of SP or RP at low rate (65\%), i.e, $52.5 \mathrm{KgP}_{2} \mathrm{O}_{5}$ of $\mathrm{RD}$ ) with gypsum (G), sulphur (S)and phosphorein(Phn)

The main results were as follows:

1-Addition of super phosphate(SP) at $65 \%$ of the recommended phosphorus rate(RD) with gypsum(G) and phosphorein(Phn) as soil amendment had a significant effect on number of leaves per plant, plant height, roots\& shoots and total dry weights per plant as well as relative dry weight (\%)during the two seasons.

2-Application of rock phosphate (RP) at $65 \%$ of the recommended phosphorus rate $R D$ ) resulted in significant decrease of foliage concentration of $N$ and $P$ as well as the $\mathrm{N}, \mathrm{P}, \mathrm{K}$ total uptake from N,P,K in both seasons.

3-The highest significant $\mathrm{N}$ and $\mathrm{P}$ concentration and $\mathrm{N}, \mathrm{P}$ and $\mathrm{K}$ uptake were resulted from application of super phosphate (SP) at $65 \%$ from RD in the presence of gypsum $(\mathrm{G})$ and phosphorein (Phn) at both seasons.

4-Addition of the recommended phosphorus rate as super phosphate(SP) or applying (SP) at $65 \%$ from RD with gypsum and phosphorein showed the most superior effect regarding average fruit weight, number of fruits and fruit yield of tomato plant as well as total yield per feddan.

5-Application of super phosphate (SP) at $65 \%$ with gypsum (G) and phosphorein (Phn) resulted in $6.45 \%$ increment in the total yield comparing to the control treatment (average of the two seasons).

6-Applying super phosphate (SP) at 65\% from RD with gypsum (G) and phosphorein (Phn) showed the superior significant values for most fruit quality, i.e., T.S.S \%, Vit $\mathrm{C}$ and total carbohydrates content of tomato fruits.

In general, this study demonstrated that it is possible to produce highest growth, yield and quality of tomato plants by applying super phosphate at $65 \%$ of the recommended phosphorus rate with 2.5 ton/feddan of gypsum and $1 \mathrm{~kg} / \mathrm{feddan}$ of phosphorein. Moreover, the phosphatic fertilization can be reduced by $35 \%$ of the recommended rate beside reduction of chemical pollution. 


\section{INTRODUCTION}

Tomato is one of the most important vegetable crops in worldwide. Fertilization efficiency availability and the uptake of $\mathrm{N}, \mathrm{P}$ and $\mathrm{K}$ elements and others macronutrients known to be high attributed with the soil conditions. Phosphorus is one of the major element for both growth and productivity,its shortage within plant tissue resulted in reduction in foliage and roots expansion (Fredeen et al., 1989),loss in photosynthetic efficiency (Lauer et al., 1989), reduction in nutrients uptake, decrease in bioassimilates transportation and the whole energy and metabolitic machinery (Marschner,1995), drastic depression in yield mass and quality (Lopez et al., 1998). Phosphorus deficiency is widespread and phosphorus fertilizers are almost universally required to maintain crops production because when it is added $\left(\mathrm{P}_{2} \mathrm{O}_{5}\right)$ to the alkaline soil only small part of phosphorus is utilized by plants and the rest is converted into insoluble fixed form ( Rodriguez and Fraga, 1999).

To maximize phosphorus fertilizers efficiency and improve growth, mineral composition and productivity of tomato, it was suggested to apply calcium super phosphate or rock phosphate alone or in different combinations with sulfur products (mineral sulpher and / or gypsum) and phosphorus solubilizing bacteria(Bacillus megatherium var.phosphaticum) under the commercial name of phosphorein (Radwan,1983;Tuna et al.,2007andTuran et al., 2007).It was reported that mineral sulpher when incorporated into soil considerably increase solubility of phosphorus under alkaline soil condition (Rivera and Irgazarry, 1984) on pepper due to its acid reaction in soil and producing sulphoric acid $\left(\mathrm{H}_{2} \mathrm{SO}_{4}\right)$ and consequently increased viability of phosphorus and other elements, i.e., $\mathrm{Cu}, \mathrm{B}, \mathrm{Fe}, \mathrm{Zn}$ and Mn (Topcuoglu and Yalcin, 1997) on tomato, Rahman and Hoque, 1994 on eggplant); improving growth and chlorophyll content (Topcuoglu and Yalcin,1997) on tomato, enhancing fruit yield and quality (Topcuoglu and Yalcin, 1997) on tomato.

On the other hand, incorporation of gypsum $\left(\mathrm{CaSO}_{4}-2 \mathrm{H}_{2} \mathrm{O}\right)$ mixed with the soil tend to improve physical and chemical properties, reducing the value of $\mathrm{pH}$, increased availability of $\mathrm{N}, \mathrm{P}, \mathrm{K}, \mathrm{Fe}, \mathrm{Mn}$ and $\mathrm{Zn}$ (Awad et al., 2002). In addition Tuna et al.,(2007) work on tomato plants they reported that applying different sulpher products in $\mathrm{SO}_{4}$ form in combination with different phosphorus fertilizers decreased the rate of phosphate fixation, increased its solubility, enhanced uptake and use efficiency, improved growth and fruit productivity.

Many biological and microbial procedures suggested that it can be maximizing the efficiency and benefits of the applied phosphorus fertilizers by inoculation of soil or plant roots mainly with that known as phosphorus solubilizing bacteria.

Rock phosphate was particularly effective in acid soils, at alkaline soil the obtained yield under the case of using rock phosphate treatments was less by 20 to $40 \%$ than using super phosphate (Mengel and Kirkby, 1978). Rock phosphate found to be more solubility, availability and uptake of phosphorus due to the applied phosphorus solubilizing bacteria (Radwan, 
1983), it reduced the soil PH (Hewedy, 1999), improved growth foliage N, P and $\mathrm{K}$ content, fruit yield and quality of tomato (Hewedy, 1999; Bardisi and Atia, 2005) on tomato. Turan et al., (2007) use different $\mathrm{P}_{2} \mathrm{O}_{5}$ fertilizers, i.e. normal and triple supper phosphate, rock phosphate they found that phosphorus solubilizing bacteria decreased soil $\mathrm{pH}$, increased availability and uptake of phosphorus from all phosphorus fertilizers, improved growth and dry mass of tomato plants. Moreover, Kamal (2008) demonstrated that application of gypsum at rate of four ton/feddan of as soil amendments and 1 $\mathrm{kg}$ of phosphorein as transplants inoculation with 60 or $90 \mathrm{~kg} \mathrm{P}_{2} \mathrm{O}_{5}$ of rock phosphate induced a significant effect on growth, yield and quality of pepper plants.

The effect of phosphorus solubilizing bacteria in solublization of phosphorus fertilizers is generally due to the production of organic acids (Sundara et al., 2002) on sugar cane and Turan et al., 2007 on tomato). Moreover, the microbial based mechanisms to improve the agronomic effectiveness of rock phosphate and phosphate fertilizers are well proved and reported by Arcanda and Schneider (2006) who reported that biological excretion of $\mathrm{H}^{+}$ions and organic acids (citric, gluconic and oxalic) by phosphorus solubilizing bacteria decreased soil $\mathrm{pH}$, releasing $\mathrm{Ca}$ from rock phosphate and super phosphate.

The main purpose of this research is to study the effect of two sources of phosphorus fertilizers rates and their combinations with sulphur, gypsum and biofertilizer phosphorien on growth, mineral composition, and yield and fruit quality of tomato.

\section{MATERIALS AND METHODS}

Tow field experiments were conducted during the two successive summer seasons of 2007 and 2008 at Kalabshow area, Dakahlia governorate, Egypt.

On $1^{\text {st }}$ March during the two seasons, tomato $\mathrm{cv}$. super marmand seedlings were transplanted in the open field into one side ridge. Each experimental unit was $25 \mathrm{~m}^{2}$ consisted of five ridges each of $5 \mathrm{~m}$ long and 1 $\mathrm{m}$ wide with $0.5 \mathrm{~m}$ planting space. Some physical and chemical properties of the experimental soil are presented in Table 1.

Table 1 .Some physical and chemical properties of the experimental of the soil during 2007 and 2008 seasons.

\begin{tabular}{|c|c|c|c|c|c|c|c|c|c|}
\hline \multirow{2}{*}{$\underbrace{\text { Parameters }}_{\text {Seasons }}$} & \multicolumn{3}{|c|}{ Texture\% } & \multirow{2}{*}{$\begin{array}{l}\text { OM } \\
\%\end{array}$} & \multirow{2}{*}{$\begin{array}{c}E C \\
\left(\mathrm{dSm}^{-1}\right)\end{array}$} & \multirow{2}{*}{ PH } & \multirow{2}{*}{$\begin{array}{c}\mathrm{N} \\
\mathrm{ppm}\end{array}$} & \multirow{2}{*}{$\begin{array}{c}\text { P } \\
\text { ppm }\end{array}$} & \multirow{2}{*}{$\begin{array}{c}\mathrm{K} \\
\mathrm{ppm}\end{array}$} \\
\hline & Sand & Silt & Clay & & & & & & \\
\hline & & & & & & & & & \\
\hline $2^{\text {nd }}$ seasons & 51.40 & 23.63 & 21.71 & 1.01 & 1.78 & 7.8 & 16.65 & 5.28 & 114 \\
\hline
\end{tabular}

A complete randomized block design with three replicates was adopted. The experiment included 14 treatments as follows:

1- Super phosphate $\left(15.5 \% \mathrm{P}_{2} \mathrm{O}_{5}\right) ; 100 \%$ of recommended $\mathrm{P}$ rate (RD) $\left(75 \mathrm{~kg} \mathrm{P}_{2} \mathrm{O}_{5} /\right.$ fed.) as a control treatment. 
EL-Said, M. E.

2 - Super phosphate $65 \%$ of RD, i.e, $52.5 \mathrm{~kg} \mathrm{P}_{2} \mathrm{O}_{5} /$ fed.

3- Super phosphate $65 \%$ of RD + phosphorein (Phn) $1 \mathrm{~kg} / \mathrm{feddan}$.

4- Super phosphate $65 \%$ of RD + Sulphur $(99.9 \% \mathrm{~S})$ at rate of $250 \mathrm{~kg} / \mathrm{fed}$.

5 - Super phosphate $65 \%$ of RD + gypsum $(18.6 \% \mathrm{~S}) 2.5$ ton/ fed.

6 - Super phosphate $65 \%$ of RD + Sulphur $250 \mathrm{~kg} / \mathrm{fed}$.

+ Phosphorein at $1 \mathrm{~kg} /$ fed.

7- Super phosphate $65 \%$ of RD + Gypsum at 2.5 ton / fed + Phosphorein at 1 $\mathrm{kg} /$ fed.

8- Rock phosphate $22 \% \mathrm{P}_{2} \mathrm{O}_{5} ; 100 \%$ of recommended $\mathrm{P}$ rate ,i.e,(RD) $75 \mathrm{~kg}$ $\mathrm{P}_{2} \mathrm{O}_{5} /$ fed.

9 - Rock phosphate $65 \%$ of recommended $\mathrm{P}$ rate $\left(52.5 \mathrm{~kg} \mathrm{P}_{2} \mathrm{O}_{5} /\right.$ feddan $)$

10- Rock phosphate $65 \%$ of RD + phosphorein (Phn.) at $1 \mathrm{~kg} / \mathrm{fed}$.

11- Rock phosphate $65 \%$ of RD + Sulphur $(99.9 \%$ S) at rate $250 \mathrm{~kg} / \mathrm{feddan}$.

12- Rock phosphate at rate of $65 \%$ + gypsum at rate $(23 \% \mathrm{Ca}$ and $18 \% \mathrm{~S})$

2.5 ton/ fed.

13- Rock phosphate at rate of $65 \%$ of RD + Sulphur $(99.9 \% \mathrm{~S})$ at rate $250 \mathrm{~kg}$ /feddan.

+ Phosphorein at $1 \mathrm{~kg} / \mathrm{fed}$.

14- Rock phosphate $65 \%$ of RD + Gypsum at rate (23\% Ca and $18 \% \mathrm{~S}) 2.5$ ton/ fed. + Phosphorein at $1 \mathrm{~kg} /$ fed.

Super phosphate, rock phosphate, sulphur and gypsum were applied before planting at rowing preparation. Phosphorein contains "Bacillus megatherium var. phosphaticum" (pure local strain) as phosphate dissolving bacteria were obtained from biofertilizer production unit, Soil and Water Res. Inst., Agric., Res. Center, Giza, Egypt. At transplanting tomato seedlings were treated with a suspension of $1 \mathrm{~kg}$ of phosphorein which dissolved in 4 liter of tap water and mixed with Arabic gum, as an adhesive substance. $\mathrm{N}$, $\mathrm{K}$ fertilizer and the other practices were applied as recommended of Ministry of Agriculture.

\section{The following data were recorded.}

First: vegetative growth parameters

At 70days after transplanting five plants from each plot were randomly taken with their roots for determination growth parameters in terms plant height $(\mathrm{cm})$, number of leaves, root, shoot and total dry weights $(\mathrm{g})$. Also, dry weight (\%) was calculated as percent of dry weight of each treatment relative to the control $(100 \%$ of recommended phosphorus rate as super phosphate).

\section{Second:chemical composition}

Mineral composition was determined in terms of total uptake and concentration (\%) of $\mathrm{N}, \mathrm{P}$ and $\mathrm{K}$ in plant samples which taken from each plot at the same times of vegetative growth samples. Total nitrogen was determined according to the methods described by Bremner and Mulvaney (1982), phosphorus was estimated colormetrically according to Olsen and Sommers (1982) and potassium was also determined using flame photometrically method as described by Jackson (1973). Then their uptake calculated considering their concentration (\%) and plant dry weight. 


\section{Third:fruit yield and its components}

Fruit yield and its components were determined from the cumulative fruit harvesting (number and weight) of each plot, then number of fruits per plant, average fruit weight(g), fruit yield per plant and total yield (ton/fed.). Also, relative yield (\%) was calculated as percent of total yield of each treatment relative to the control $(100 \%$ of recommended $P$ rate as super phosphate).

\section{Fourth: fruit quality}

Arepresentative sample of 5 fruits from each experimental plot at the marketable ripe stage were taken from the $4^{\text {th }}$ harvest for determination of total soluble solids (TSS), vitamin C and titratable acidity according to the methods of A.O.A.C. (1990).

Total carbohydrates were estimated in fresh fruit weight according to method of Mitchal et al., (1956).

The obtained data were subjected to statistical analysis according to Gomez and Gomez (1984). The treatment means were compared using New Least Significant Difference at $5 \%$ level of probability as mentioned by Waller and Duncan (1969).

\section{RESULTS AND DISCUSSION \\ First: Vegetative growth parameters}

Data presented in Table 2 show the effect of different sources of phosphorus fertilizers, i.e., super phosphate and rock phosphate that applied at $100 \%$ and $65 \%$ of the recommended phosphorus rate and their combinations with mineral sulpher, gypsum and phosphorein on tomato growth parameters, i.e., number of leaves, plant height, roots, shoots and total dry weight as well as the relative dry weight of tomato plant, during 2007 and 2008 seasons. It is evident clear from such data that the individual treatments and combinations of super phosphate fertilizer considerably enhanced all growth parameters of tomato plants than those of rock phosphate fertilizer in both seasons.

Application of either supper phosphate and / or rock phosphate alone at low phosphorus rate at $(65 \%$ of the recommendation) resulted in considerable reduction in all growth parameters i.e. plant height, number of leaves/ plant, shoot and root dry weight of tomato. It is clear that the addition of super phosphate at $65 \%$ of the recommended rate with gypsum and phosphorein as soil amendment had a significant effect on number of leaves per plant, plant height, roots, shoots and total dry weights per plant as well as relative dry weight (\%) in both seasons.

These results were in line with those obtained by Fredeen et al., (1989) on Glycine max plants; Topcuoglu and Yalcin ,(1997) on tomato; Awad et al., (2002) on potato, Tuna et al., (2007) on tomato and Kamal ,(2008) on pepper plants.

The growth enhancement due to application of phosphorus fertilizer with gypsum or mineral sulpher may be not only due to their reducible effect of the soil $\mathrm{pH}$, render phosphorus and other elements to be in more soluble and available form for plant (Rivera and Lrgazarey, 1984) on pepper 


\section{EL-Said, M. E.}

,Topcuoglu and Yalcin, 1997 ; Turan et al ., 2007 ) on tomato but also due to supplementation of sulpher and calcium into tomato plants and in turn their structural and regulatory functions and involvements within plant tissues, i.e., sulpher as methionine, cystein and protein components, also component of gluathion (antioxidant) and sulpholipids and enzymes functions (Dekok et al., 2002). As well as the role of calcium in membrane stability and selectivity, carbohydrates and protein biosynthesis, cell division and signal transduction response all in relation with growth and dry matter accumulation and partitioning (Marchener, 1995). On the other hand, presence of phosphorein with the low applied rate of phosphorus fertilizers which resulted in growth encouragements also could be attributed to its enhancing effect on phosphorus uptake and the concentration, $\mathrm{N}$ and $\mathrm{K}$ in plant tissue (Table 3), this is due to its biological solublization effect, releasing phosphorus from of the applied super phosphate and rock phosphate and the soil via the biological release of $\mathrm{H}^{+}$ions, organic acids chelating and in turn better growth response even with low phosphorus supply (Sundara et al., 2002 on sugar cane; Arcanda and Schneider, 2006 and Turan et al., 2007 on tomato).

\section{Second : chemical composition}

Data in Table 3 showed the impact of the applied phosphorus fertilization treatments on both concentration and total uptake of $\mathrm{N}, \mathrm{P}$ and $\mathrm{K}$ of tomato plants. Such data reveled that, application of super phosphate at low phosphorus rate compared with the recommended rate only resulted in significant reduction in both concentrations and total uptake of $\mathrm{N}, \mathrm{P}$ and $\mathrm{K}$ in the two seasons, whereas, application of rock phosphate alone at $100 \%$ of the recommended phosphorus rate resulted in significant reduction concentration of $\mathrm{N}$ and $\mathrm{P}$ as well as significant resulted for $\mathrm{N}, \mathrm{P}$, and $\mathrm{K}$ total uptake in two seasons .

Also, it was observed that different combinations of super phosphate fertilizer tended to be more effective than rock phosphate combinations with improving mineral status of tomato plants particularly in minerals foliage concentration and total uptake. The same data showed also that application of gypsum or sulphur amendments and inoculation the seedling roots with phosphorein at different combinations with low rate of super phosphate was greatly improved and recovered mineral status of tomato plants, in this respect the highest significant $\mathrm{N}$ and $\mathrm{P}$ concentration and $\mathrm{N}, \mathrm{P}$ and $\mathrm{K}$ uptake resulted from application of super phosphate at low rate phosphorus with gypsum and phosphorein, it was not only restored mineral status of tomato plants but also more superior on the mineral status of the plants that received the recommended phosphorus fertilizer (super phosphate at $100 \%$ of recommended phosphorus rate). On the other hand, the applied phosphorus fertilizer in the form of super phosphate or rock phosphate at rates 100 and / or $65 \%$ of the recommended rate of phosphorus and their combinations with sulphur, gypsum and phosphorein did not show significant effect on potassium concentration in tomato plant foliage in both seasons.

These results and interpretation were confirmed by those obtained by Topcuoglu and Yalcin,(1997) on tomato, Awad et al.,(2002) on potato; Sundara et al.,(2002) on sugar cane; Arcanda and Schneider,(2006) and Tuna et al.,(2007) on tomato and Kamal,(2008) on pepper plants. 
J. Agric. Sci. Mansoura Univ., 34 (5), May, 2009

T2-3

4835 
EL-Said, M. E.

Under present works condition the effect of all treatments on N, P and $\mathrm{K}$ concentration in tomato plant tissue and total uptake of tomato plants could be attributed based on the known role of gypsum due to lowering the soil $\mathrm{pH}$ via the direct acidifying effect of $\mathrm{SO}_{4}$ and indirectly due to $\mathrm{Ca}$ uptake that corresponded with realizing of $\mathrm{H}^{+}$ions, also, $\mathrm{SO}_{4}$ known to be reduce the capacity of soil to fixing $\mathrm{PO}_{4}$ ions (Awad et al., 2002) on potato;(Tuna et al.,2007) on tomato. Furthermore, mineral sulpher is biologically oxidized in soil with time into $\mathrm{SO}_{4}$ and inturn reducing the soil $\mathrm{pH}$, improving phosphorus fertilizers dissociation, soil and plant phosphorus status, also, uptake and concentration of N and K (Topcuoglu and Yalcin, 1997) on tomato; (Rahman and Hoque, 1994) on eggplant.

\section{Third: fruit Yield and its components}

Data presented in Table 4 illustrate the effect of the applied phosphorus fertilizer super phosphate and rock phosphate at rates of 100 and $65 \%$ of the recommended rate phosphorus and their combinations with sulpher, gypsum and phosphorein on average fruit weight, number of fruits, fruit yield of tomato plant as well as total yield per feddan and relative yield (\%), during 2007 and 2008 seasons. Such data indicated that, using the recommended phosphorus rate as super phosphate or applying supper phosphate at the low phosphorus rate $(65 \%)$ of the recommendation with gypsum and phosphorein showed the most superior effect regarding average fruit weight, number of fruits, fruit yield of tomato plant as well as total yield per feddan, this was also true for rock phosphate combinations compared only with rock phosphate alone at $100 \%$ of phosphorus during both seasons. Based on relative yield values, it was found that the most superior treatment was super phosphate at low rate with gypsum and phosphorein which the total yield increases by $6.45 \%$ (average of the two seasons) followed by supper phosphate at $100 \%$ of the recommended phosphorus rate.

The obtained results and the suggested interpretation were confirmed by finding obtained by Fredeen et al. (1989) on Glycine max plants; Marchener,(1995) ; Topcuoglu and Yalcin,(1997) ; Awad et al., (2002) ;Tuna et al.,(2007); and Turan et al., (2007) on tomato on super phosphate and rock phosphate; working on mineral sulpher; Hewedy (1999); Bardisi and Atia,(2005) and Turan et al.,(2007) working on phosphorus solubilizing bacteria.

The above mentioned cited interpretation and explanation due the application of low phosphorus rate, gypsum and phosphorein may be due to thier enhancing impact on root and foliage growth of tomato plants (Table 2), that associated with the potentiality of nutrient uptake (Table 3 ) and bioassimilation process of the whole metabolic machinery, those known to be reflected in similar beneficial way on fruit yield responses of tomato plants.

\section{Fourth: Fruit quality}

Data concerned in table 5 show the effect of applied phosphorus fertilizer in the form of super phosphate and rock phosphate at rates $100 \%$ and $65 \%$ of the recommended phosphorus rate and their combinations with sulphur at the rate of Sulphur $(99.9 \% \mathrm{~S})$ at rate of $250 \mathrm{~kg} / \mathrm{fed}$. gypsum at the rate $(18.6 \%$ S) $2.5 \mathrm{ton} / \mathrm{fed}$. and phosphorein on tomato fruit quality. 
J. Agric. Sci. Mansoura Univ., 34 (5), May, 2009

T4-5

4837 


\section{EL-Said, M. E.}

It was evident from such data that reducing rate of applied supper phosphate and / or rock phosphate to $65 \%$ of the recommended phosphorus rate resulted in significant reduction in all studied tomato fruit quality characters including TSS \%,vit.C and total carbohydrate contents except those of fruits titratable acidity which showed no significant differences during the two seasons. The same data indicated that applications of $100 \%$ of the recommended phosphorus rate as supper phosphate or applying supper phosphate at low phosphorus rate at $(65 \%)$ with gypsum and phosphorein showed the most significant values for most of fruit quality,i.e., TSS \%,vit C and total carbohydrates content of tomato fruits in two seasons.

Similar results were obtained by Topcuoglu and Yalcin, (1997) on tomato; Awad et al.,(2002) on potato; Bardisi and Atia,(2005) on tomato and Tuna et al.,(2007) on tomato.

Under this work condition, these results could be explained based on the previously observed beneficial effects of the same treatments in similar way on their plants growth and dry matter accumulation, contents of $\mathrm{N}, \mathrm{P}$ and $\mathrm{K}$ in plant tissues (Tables 2 and 3 ). Also, fruits mass were greatly associated with dry matter and bioassimilates formation within foliage parts and their subsequent partitioning into reproductive sinks (Marchener, 1995).

\section{Conclusion:}

This investigation could suggest that application of superphosphate at $65 \%$ of recommended rate / feddan and gypsum (18.6\% S) $2.5 \mathrm{ton} / \mathrm{fed}$. with combination of inoculation tomato seedlings with the biofertilizers phosphrien indispensable for optimum tomato productivity and maximum yield .Moreover, the addition biofertilizers would decrease chemical pollution of environmental and the production costs.

\section{REFERENCES}

A.O.A.C. (1990). Official Method of Analysis. $10^{\text {th }}$ Association of Official Analytical Chemists. Inc. USA.

Arcanda, M. M. and K. D. Schneider (2006). Plant and microbial based mechanisms to improve the agronomic effectiveness of phosphate rock. An. Acad. Bras. Ciene., 78 (4): 791-807.

Awad, E. M.; E. A. A. Tartora; H. M. El-Foly and A. I. Abd El-Fattah (2002). Response of potato growth,yield and quality to farmyard manure, sulphur and gypsum levels application. $2^{\text {nd }}$ Inter, Conf. Horti. Sci.10:12 Sep. Kafr El-Sheikh, Tanta Univ. Egypt.

Bardisi, A. and N. A. Atia (2005). An attempt to minimize the addition of mineral phosphorus fertilizer by using biofertilizer in tomato plants. The $6^{\text {th }}$ Arabian Conference for Horticulture, Ismailia, Egypt, pp.205-221.

Bremner, J. M. and C. S. Mulvaney (1982). Total Nitrogen. In: Page, A. L., R. $H$. Miller and D. R. Keeney (eds.) Methods of Soil Analysis. Part 2, Amer. Soc. Agron. Madison, W I. USA, pp.595- 624.

Dekok, L. J.; A. Castro; M. Dyrenkamo; C. E. E. Stuiver; S. Westerman; L. Yang, and L. Stulen (2002). Sulfur in plant physiology. Proc. No. 500, The international Ferti., Soci. York, USA, pp.1-26. 
Fredeen, A. L.; I. M. Rao and N. Terry (1989). Influence of phosphorus nutrition on growth and carbon partitioning in Glycine max. Plant Physiol.,89: 225-230.

Gomez, K.A. and A.A. Gomez (1984). Statistical Rocedures for Agricultural Research $2^{\text {nd }}$ Ed. John Wiely and Sonic, P. $139-153$.

Hewedy, A. M. (1999). Effect of sulfur application and biofertilizer phosphorein on growth and productivity of tomato. Minufiya J. Agric. Res., 24(3):1063-1078.

Jackson, M. L. (1973). Soil Chemical Analysis. Prentic-Hall, India, pp.144197.

Kamal, A. M. (2008). Effect of gypsum, phosphoreine and rock phosphate on growth and yield of sweet pepper plants. J. Agric. Sci. Mansoura Univ., 33 (12): $8709-8722$.

Lauer, M. J.; D. G. Blevins; H. S. Gracz and P. nuclear (1989). Magnetic response determination of phosphate compartmentation in leaves of reproductive soybeans (Glycine max L.) affected by phosphate nutrition .Plant physiol., 89 : 1331-1336.

Lopez I. C. L; J. M. Rurz; j. Hernandez and L. Romero (1998). Phosphorus metabolism and yield response to increases in nitrogen,phosphorus fertilization: Improvement in greenhouse cultivation of eggplant (Solanum meleongena cv. Bonica). J. Agric. Food Chem., 46:16031608.

Marschner, H. (1995). Mineral Nutrition of Higher Plants. Academic Press, London.

Mengel, K. and E. A. Kirkby (1978). Principles of Plant Nutrition. International Potash Institute, P.O. Box CH. 3048, Worblaufed Bern, Switzerland.

Michel, K. A.; Gilles, J. K.; Ramilton, R. P. A. and F. Smith (1956). Colorimetric method for determination of sugars and related substances. Annal Chem., 28(3):350-356.

Olsen, S. R. and L. E. Sommers (1982). Phosphorus. In: Page, A. L.; R. H. Miller and D. R. Keeney (eds). Methods of Soil Analysis. Part 2 Amer. Soc. Agron. Madison, W. I. USA. pp. 403-430.

Radwan, S. M. A. (1983). Effect of inoculation with phosphate dissolving bacteria on some nutrients uptake from newly cultivated soil M.Sc. Thesis, Fac. Agric. Ain Shams Univ. Egypt.

Rahman, M. and M. M. Hoque (1994). Yield response of brinjal (Solanum meleongena L.) to sulphur fertilizer. Bangladesh J. Sci. and Idust. Res. 29 (4) 151.

Rivera, E. and H. Irgazarry (1984). Effect of fertilization with phosphorus, sulpher and micronutrients on yields of peppers growing on an alkaline soil, J. Agric. Univ., Puerto Rico. 68 (1) : 1-4.

Rodriguez, $H$. and R. Fraga (1999). Phosphate solubilizing bacteria and their role in plant growth promotion. Biotechnology Adv..17: 319-339.

Sundara, B.; V. Natarajam and K. Harik (2002). Influence of phosphorus solubilizing bacteria on the change in soil availability phosphorus and sugar cane and sugar yield of sugar cane Field Crops Res., 77: 43-49.

Topcuoglu, B. and S. R. Yalcin (1997). Effects of elemental sulpher applications to calcareous soil on yield and quality properties and some plant nutrient contents of tomato plant grown under covered conditions Ziraat-Fakultesi-Dergisi,-Akdeniz-Universitesi,10 (1):196210. 


\section{EL-Said, M. E.}

Tuna, L. A.; K. Cengiz; M. Ashraf; H. Altnulu; I. Yokas and B. Yagmur (2007). The effect of calcium sulphate on growth, membrane stability and nutrient uptake of tomato plants grown under salt stress. Envir Experi. Bot., 59 : 173-178.

Turan, M.; N. Ataoglu and F. Sahin (2007). Effect of Bacillus FS $^{-3}$ on growth of tomato (Lycopersicon esculantum L.) Plants and availability of phosphorus in soil. Plant Soil Environ.,53 (2) : 58-64.

Waller, R. A. and D. B. Duncan (1969). A bayes for the symmetric multiple comparison problem. J. Amer. Stat. Assoc., 64 : 1484-1503.

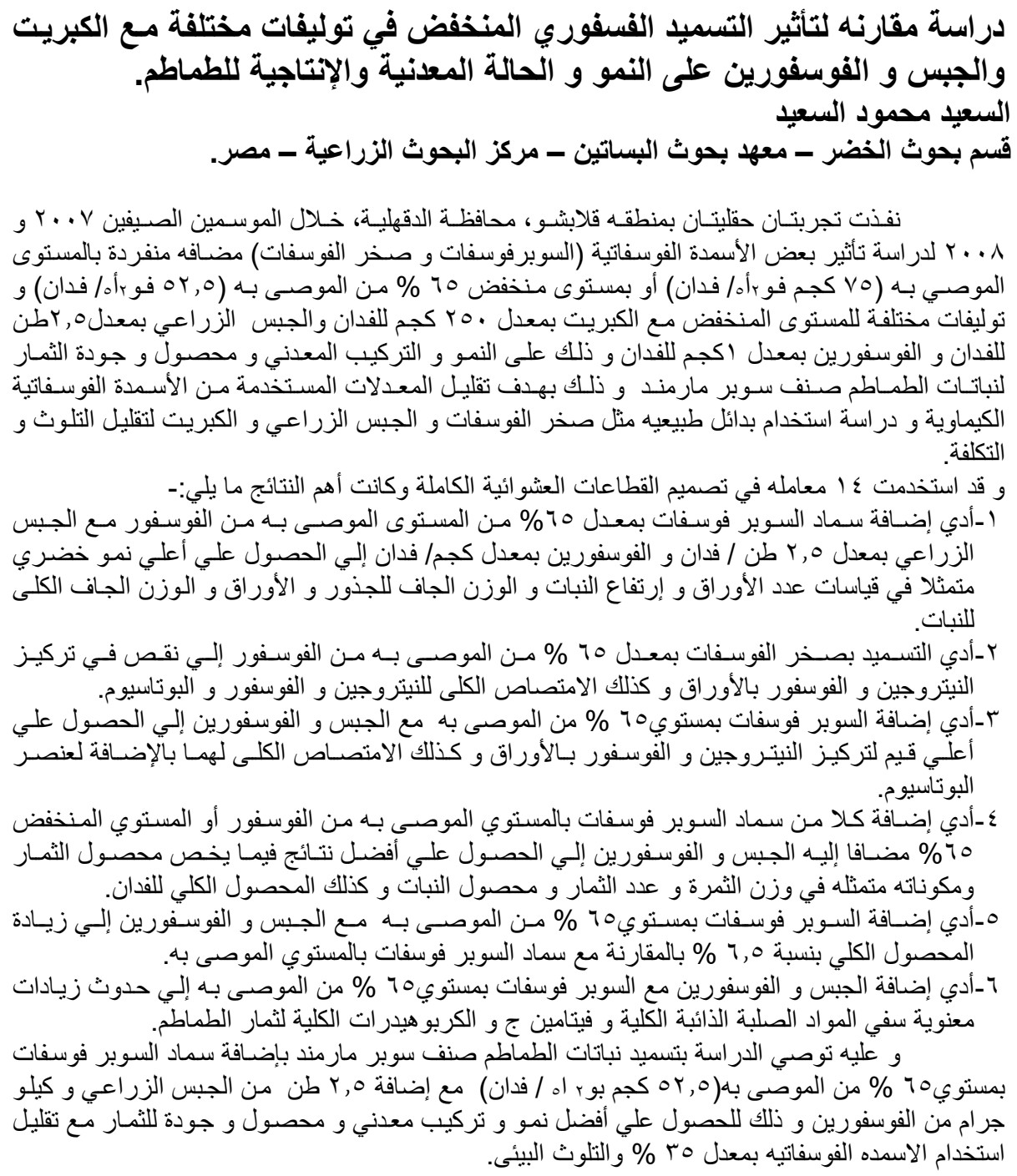


J. Agric. Sci. Mansoura Univ., 34 (5), May, 2009

4841 
Table 2: Effect of super phosphate, rock phosphate, sulphur, gypsum and phosphorein on vegetative growth of tomato during 2007 and 2008 seasons.

\begin{tabular}{|c|c|c|c|c|c|c|c|c|c|c|c|c|}
\hline \multirow[b]{3}{*}{ Treatments } & \multicolumn{6}{|c|}{ Season 2007} & \multicolumn{6}{|c|}{ Season 2008} \\
\hline & \multirow[b]{2}{*}{$\begin{array}{l}\text { No. } \\
\text { leaves / } \\
\text { plant }\end{array}$} & \multirow[b]{2}{*}{$\begin{array}{c}\text { Plant } \\
\text { height } \\
\text { (cm) }\end{array}$} & \multicolumn{4}{|c|}{ Dry weight /plant (g) } & \multirow[b]{2}{*}{$\begin{array}{c}\text { No. } \\
\text { leaves / } \\
\text { plant }\end{array}$} & \multirow[b]{2}{*}{$\begin{array}{c}\text { Plant } \\
\text { height } \\
\text { (cm) }\end{array}$} & \multicolumn{4}{|c|}{ Dry weight /plant (g) } \\
\hline & & & Roots & shoots & Total & $\begin{array}{c}\text { Relative } \\
\text { D.W. } \\
\% \text { I }\end{array}$ & & & Roots & shoots & Total & $\begin{array}{c}\text { Relative } \\
\text { D.W. } \\
\%\end{array}$ \\
\hline SP $100 \%$ of RD (control) & 111.3 & 87.5 & 9.04 & 79.89 & 88.93 & 100 & 105.0 & 79.6 & 8.24 & 76.21 & 84.45 & 100 \\
\hline SP $\quad 65 \%$ of RD & & 78 & 6.4 & 1 & & 79 & & & & & & 79.5 \\
\hline SP $65 \%+$ Phn & 96.7 & 84.2 & 7.02 & 70.10 & 77.12 & 86 & & 75 & 6. & 66 & 72 & 85.9 \\
\hline SP $65 \%+S$ & 100.3 & 83.9 & 7.34 & & 82.5 & 92 & & & 7. & & & 100.1 \\
\hline SP $65 \%+S+P h n$ & 108 & 82.6 & 8.04 & 81.2 & 89.32 & 100.4 & 10 & 74 & 7. & & 87.18 & 103.2 \\
\hline SP $65 \%+G$ & & & 8.03 & & & & & & 7. & & & \\
\hline SP $65 \%+G+P h n$ & 123 & 90.7 & 9.3 & 88. & 97.79 & $10 s$ & 113 & 83 & 9. & 91. & 100.51 & 119.0 \\
\hline RP $100 \%$ of RD & & 81.9 & 7.24 & & & & & 73 & 6. & & & 88.7 \\
\hline RP $65 \%$ of RD & & 74.1 & 4.76 & 50. & 55. & 62 & & $6 s$ & 4. & & & 60.1 \\
\hline RP $65 \%+$ Phn & 88.7 & 76.6 & 6.07 & 58.24 & 64.31 & 72.3 & 83.9 & 72.4 & 6.11 & 55.14 & 61.25 & 72.5 \\
\hline RP $65 \%+S$ & 86.3 & 78.0 & 6.28 & 61.37 & 67.65 & 76.1 & & 71 & 6. & & & 76.3 \\
\hline RP $65 \%+S+P h n$ & 95.5 & 80.3 & 6.91 & 67.12 & 74.03 & 83.2 & 91.2 & 74.9 & 6.71 & 61.57 & 68.28 & 80.8 \\
\hline RP $65 \%+$ G & 93 & 82.0 & 7.5 & & 76.62 & 86 & & 76 & 7.41 & & & 86.3 \\
\hline $\mathrm{RP} 65 \%+\mathrm{G}+\mathrm{Phn}$ & 98. & 84.9 & 7.87 & 76.17 & 84.04 & 94.9 & & 79 & 7.91 & 70.18 & 78.09 & 92.5 \\
\hline New L.S.D.(0.05) & 7.21 & 5.01 & 0.87 & 6.61 & 8.04 & & 8.13 & 4.76 & 0.95 & 8.87 & 11.04 & \\
\hline
\end{tabular}

$\mathbf{S P}=$ Super phosphate $\mathbf{R D}=$ Recommended $\mathbf{P}$ rate $\mathbf{P h n}=$ Phosphorein $\mathbf{S}=$ Sulphur $\quad \mathrm{G}=$ Gypsum $\mathbf{R P}=$ Rock phosphate

Table 3: Effect of super phosphate, rock phosphate, sulphur, gypsum and phosphorein on chemical composition of tomato during 2007 and 2008 seasons.

\begin{tabular}{|c|c|c|c|c|c|c|c|c|c|c|c|c|}
\hline \multirow{3}{*}{\begin{tabular}{|ll} 
Treatments & Characters \\
\end{tabular}} & \multicolumn{6}{|c|}{ Season 2007} & \multicolumn{6}{|c|}{ Season 2008} \\
\hline & \multirow{2}{*}{$N(\%)$} & \multirow{2}{*}{ P (\%) } & \multirow{2}{*}{ K (\%) } & \multicolumn{3}{|c|}{ Total uptake (mg/ plant) } & \multirow{2}{*}{$\begin{array}{c}\mathbf{N} \\
(\%)\end{array}$} & \multirow{2}{*}{$\begin{array}{c}P \\
(\%)\end{array}$} & \multirow{2}{*}{$\begin{array}{c}K \\
(\%)\end{array}$} & \multicolumn{3}{|c|}{ Total uptake (mg/plant) } \\
\hline & & & & $\mathbf{N}$ & $\mathbf{P}$ & $\mathrm{K}$ & & & & $\mathbf{N}$ & $\mathbf{P}$ & $\mathrm{K}$ \\
\hline SP $100 \%$ of RD (control) & 3.22 & 0.37 & 4.11 & 2854 & 334.3 & 3663 & 3.04 & 0.34 & 3.95 & 2575 & 295.3 & 3340 \\
\hline SP $65 \%$ of RD & 3.02 & 0.29 & 4.15 & 2125 & 207.6 & 2937 & 2.85 & 0.27 & 3.99 & 1922 & 183.7 & 2684 \\
\hline SP $65 \%+P h n$ & 2.98 & 0.31 & 4.28 & 2305 & 240.6 & 3308 & 2.84 & 0.29 & 4.11 & 2061 & 210.5 & 2988 \\
\hline SP $65 \%+S$ & 3.03 & 0.32 & 4.25 & 2509 & 265.8 & 3516 & 2.88 & 0.29 & 4.08 & 2441 & 253.1 & 3456 \\
\hline $\mathrm{SP} 65 \%+\mathrm{S}+\mathrm{Phn}$ & 3.20 & 0.35 & 4.16 & 2867 & 304.1 & 3724 & 3.04 & 0.31 & 4.02 & 2658 & 276.4 & 3489 \\
\hline SP $65 \%+G$ & 3.31 & 0.34 & 4.17 & 2922 & 305.5 & 3690 & 3.14 & 0.32 & 4.01 & 2797 & 286.3 & 3570 \\
\hline SP $65 \%+G+P h n$ & 3.42 & 0.38 & 4.21 & 3334 & 371.6 & 4126 & 3.23 & 0.35 & 4.05 & 3256 & 355.2 & 4071 \\
\hline RP $100 \%$ of RD & 2.96 & 0.28 & 4.06 & 2330 & 222.8 & 3193 & 2.82 & 0.26 & 3.91 & 2114 & 197.9 & 2928 \\
\hline RP $65 \%$ of RD & 2.88 & 0.24 & 4.24 & 1606 & 138.3 & 2362 & 2.74 & 0.23 & 4.07 & 1394 & 117.6 & 2072 \\
\hline RP $65 \%+$ Phn & 2.93 & 0.29 & 4.15 & 1871 & 189.0 & 2675 & 2.76 & 0.27 & 3.99 & 1693 & 167.4 & 2446 \\
\hline RP $65 \%+S$ & 2.89 & 0.28 & 4.21 & 1961 & 202.9 & 2854 & 2.75 & 0.27 & 4.05 & 1775 & 179.7 & 2610 \\
\hline RP $65 \%+S+P h n$ & 2.91 & 0.31 & 4.19 & 2154 & 230.2 & 3109 & 2.76 & 0.28 & 4.03 & 1887 & 197.4 & 2753 \\
\hline RP $65 \%+G$ & 3.03 & 0.31 & 4.10 & 2306 & 241.3 & 3149 & 2.85 & 0.29 & 3.94 & 2084 & 213.5 & 2875 \\
\hline RP $65 \%+G+P h n$ & 3.11 & 0.33 & 4.23 & 2613 & 280.6 & 3563 & 2.95 & 0.31 & 4.06 & 2307 & 242.5 & 3178 \\
\hline New L.S.D.(0.05) & 0.17 & 0.031 & N.S. & 324.1 & 25.6 & 398.4 & 0.18 & 0.033 & N.S. & 411.6 & 41.6 & 422.5 \\
\hline
\end{tabular}

SP = Super phosphate $\quad \mathbf{R D}=$ Recommended $\mathbf{P}$ rate $\mathbf{P h n}=$ Phosphorein $\mathbf{S}=$ Sulphur $\mathbf{G}=$ Gypsum $\mathbf{R P}=$ Rock phosphate 
Table 4: Effect of super phosphate, rock phosphate, sulphur, gypsum and phosphorein on yield and its components of tomato during 2007 and 2008 seasons.

\begin{tabular}{|c|c|c|c|c|c|c|c|c|c|c|}
\hline \multirow[b]{2}{*}{ Treatments } & \multicolumn{5}{|c|}{ Season 2007} & \multicolumn{5}{|c|}{ Season 2008} \\
\hline & $\begin{array}{c}\text { Average } \\
\text { fruit } \\
\text { weight (g) }\end{array}$ & $\begin{array}{l}\text { No. of } \\
\text { fruits } \\
\text { /plant }\end{array}$ & $\begin{array}{c}\text { Yield/ } \\
\text { plant (g) }\end{array}$ & $\begin{array}{c}\text { Total yield } \\
\text { (ton /fed) }\end{array}$ & $\begin{array}{c}\text { Relative } \\
\text { yield (\%) }\end{array}$ & $\begin{array}{r}\text { Average } \\
\text { fruit } \\
\text { weight (g) }\end{array}$ & $\begin{array}{l}\text { No. of } \\
\text { fruits } \\
\text { /plant }\end{array}$ & $\begin{array}{c}\text { Yield/ } \\
\text { plant (g) }\end{array}$ & $\begin{array}{c}\text { Total yield } \\
\text { (ton /fed) }\end{array}$ & $\begin{array}{c}\text { Relative } \\
\text { yield } \\
(\%)\end{array}$ \\
\hline SP $100 \%$ of RD (control) & 75.68 & 29.90 & 2262 & 20.59 & 100 & 74.80 & 30.79 & 2303 & 20.96 & 100.0 \\
\hline SP $65 \%$ of RD & 65.71 & 24.42 & 1604 & 14.76 & 71.6 & 62.50 & 24.49 & 1531 & 14.39 & 68.6 \\
\hline SP $65 \%+P h n$ & 69.21 & 27.63 & 1912 & 17.40 & 84.5 & 65.28 & 26.20 & 1710 & 15.90 & 75.8 \\
\hline SP $65 \%+S$ & 71.31 & 26.86 & 1915 & 18.58 & 90.2 & 67.59 & 28.07 & 1897 & 17.83 & 85.0 \\
\hline SP $65 \%+S+P h n$ & 73.45 & 28.10 & 2063 & 19.40 & 94.2 & 69.25 & 28.75 & 1991 & 18.12 & 86.4 \\
\hline SP $65 \%+G$ & 75.44 & 27.51 & 2075 & 19.09 & 92.7 & 70.84 & 27.18 & 1925 & 18.10 & 86.3 \\
\hline SP $65 \%+G+P h n$ & 79.88 & 31.11 & 2485 & 22.61 & 109 & 77.82 & 31.09 & 2420 & 21.78 & 103.9 \\
\hline RP $100 \%$ of RD & 64.28 & 22.67 & 1457 & 13.26 & 64.4 & 62.48 & 25.33 & 1582 & 14.24 & 67.9 \\
\hline RP $65 \%$ of RD & 59.64 & 22.25 & 1326 & 12.47 & 60.5 & 57.00 & 23.82 & 1358 & 12.36 & 58.9 \\
\hline RP $65 \%+$ Phn & 62.14 & 23.88 & 1484 & 14.24 & 69.1 & 61.18 & 24.11 & 1475 & 13.86 & 66.1 \\
\hline $\operatorname{RP} 65 \%+S$ & 63.48 & 24.35 & 1545 & 14.68 & 71.2 & 62.74 & 24.89 & 1561 & 14.52 & 69.2 \\
\hline RP $65 \%+S+P h n$ & 63.40 & 24.68 & 1565 & 14.71 & 71.4 & 61.81 & 23.93 & 1479 & 13.90 & 66.3 \\
\hline $\mathrm{RP} 65 \%+\mathrm{G}$ & 68.11 & 23.07 & 1571 & 14.14 & 68.6 & 64.51 & 24.06 & 1552 & 14.28 & 68.1 \\
\hline RP $65 \%+G+P h n$ & 71.00 & 24.07 & 1709 & 15.89 & 77.1 & 68.25 & 24.71 & 1687 & 15.35 & 73.2 \\
\hline New L.S.D.(0.05) & 6.21 & 3.24 & 228.9 & 2.15 & & 5.87 & 2.15 & 301.9 & 2.41 & \\
\hline
\end{tabular}

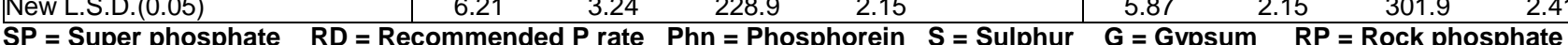

Table 5: Effect of super phosphate, rock phosphate, sulphur, gypsum and phosphorein on fruits quality of tomato during 2007 and 2008 seasons.

\begin{tabular}{|c|c|c|c|c|c|c|c|c|}
\hline \multirow{2}{*}{$\mathrm{T}_{\text {Treatments }}$ Characters } & \multicolumn{4}{|c|}{ Season 2007} & \multicolumn{4}{|c|}{ Season 2008} \\
\hline & TSS \% & Vit $\mathrm{C} \underset{\mathrm{FW}}{\mathrm{mg} / 100 \mathrm{gm}}$ & $\begin{array}{l}\text { Titratable acidity } \\
\text { (mg/100 ml juice) }\end{array}$ & $\begin{array}{c}\text { Total } \\
\text { carbohydrates }\end{array}$ & TSS $\%$ & $\begin{array}{l}\text { Vit C mg/ } \\
\text { 100gm FW }\end{array}$ & $\begin{array}{c}\text { Titratable acidity } \\
\text { (mg/100 ml } \\
\text { juice) }\end{array}$ & $\begin{array}{c}\text { Total } \\
\text { carbohydra- } \\
\text { tes }\end{array}$ \\
\hline 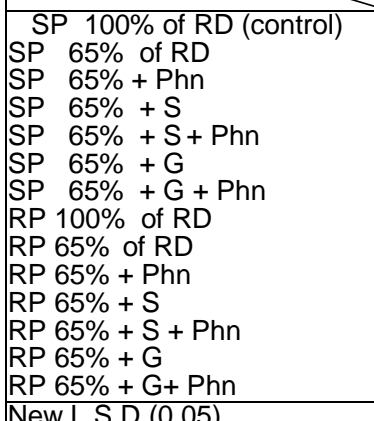 & $\begin{array}{l}5.64 \\
5.24 \\
5.31 \\
5.29 \\
5.81 \\
5.74 \\
6.04 \\
5.24 \\
5.11 \\
5.37 \\
5.16 \\
5.39 \\
5.41 \\
5.50 \\
0.341\end{array}$ & $\begin{array}{l}62.4 \\
55.4 \\
52.4 \\
51.9 \\
53.4 \\
54.1 \\
59.3 \\
53.4 \\
48.5 \\
52.7 \\
51.7 \\
49.4 \\
52.7 \\
51.4 \\
6.11 \\
\end{array}$ & $\begin{array}{l}0.70 \\
0.67 \\
0.72 \\
0.72 \\
0.71 \\
0.70 \\
0.73 \\
0.62 \\
0.64 \\
0.70 \\
0.71 \\
0.70 \\
0.72 \\
0.71 \\
\text { N.S }\end{array}$ & $\begin{array}{l}87.24 \\
79.22 \\
82.04 \\
84.17 \\
86.21 \\
85.09 \\
92.03 \\
82.36 \\
78.86 \\
80.14 \\
84.49 \\
83.64 \\
81.49 \\
80.41 \\
5.47 \\
\end{array}$ & $\begin{array}{l}5.51 \\
5.01 \\
5.19 \\
5.24 \\
5.47 \\
5.34 \\
5.64 \\
5.04 \\
5.13 \\
5.27 \\
5.28 \\
5.34 \\
5.26 \\
5.14 \\
0.187\end{array}$ & $\begin{array}{l}58.4 \\
51.1 \\
50.4 \\
54.1 \\
53.6 \\
55.1 \\
64.2 \\
50.4 \\
48.0 \\
50.4 \\
51.4 \\
52.5 \\
50.7 \\
54.8 \\
794\end{array}$ & $\begin{array}{l}0.89 \\
0.77 \\
0.81 \\
0.83 \\
0.86 \\
0.88 \\
0.91 \\
0.68 \\
0.65 \\
0.74 \\
0.71 \\
0.85 \\
0.72 \\
0.84 \\
\end{array}$ & $\begin{array}{l}78.66 \\
72.88 \\
72.71 \\
75.59 \\
74.55 \\
74.60 \\
82.06 \\
75.53 \\
77.39 \\
75.72 \\
74.05 \\
75.95 \\
72.97 \\
74.65 \\
\end{array}$ \\
\hline
\end{tabular}

SP = Super phosphate $\quad R D=$ Recommended $\mathrm{P}$ rate $\mathrm{Phn}=$ Phosphorein $\mathbf{S}=$ Sulphur $\mathbf{G}=$ Gypsum $\mathbf{R P}=$ Rock phosphate 


\section{EL-Said, M. E.}

